\title{
THE FAMILIES OF STUDENTS WITH MULTIPLE DISABILITIES IN THE EDUCATIONAL PROCESS
}

\author{
Jiř́ Kantor \\ Libuše Ludíková \\ Palacký University in Olomouc, Czech Republic
}

\begin{abstract}
This paper focuses on several aspects of the relationship between families of students with multiple disabilities and the educational process. Quality-based methodology was used for the research due to a lack of sufficient theoretical background in this area. The objective of the paper was to elucidate the significance of education of students with multiple disabilities for their families and to describe the process of cooperation between these families and the teachers. This paper uses data and outputs from a qualitative analysis of education of students with severe multiple disabilities (semi-structured interviews with 45 teachers of students with multiple disabilities, observation of 4 students in the educational process and an analysis of 30 samples of educational documents using open, axial and selective coding). The resulting theory was combined with the results of a survey focused on the cooperation between the families and the teachers in order to gain a saturated data sample. This survey used semi-structured interviews with 5 teachers of students with multiple disabilities. The data from these interviews were analysed by means of open coding, compared with the outputs of the previous research and a theoretical model for educational intervention with the families of students with multiple disabilities was constructed and described. This model offers ideas for educational practice as well as further research.
\end{abstract}

Keywords: Educational process, family, multiple disabilities.

\section{Introduction}

The paper deals with various topics connected with the families of students with multiple disabilities (SMD) and the educational process. The basic objective of the study was to identify family needs in the educational process, to map the impact of coping with children's disabilities on the education and to analyse the tasks and course of special educational intervention with families. We used data from quality-based analyses of the educational process in students with SMD (coding and categorisation of semi-structured interviews, analysis of educational documents and observation of student-teacher interaction), and a survey focused on the data concerning the family and education.

The family of a student with SMD has an essential position in the educational process. Education of this group of students requires close participation of their parents in the educational process with respect to the serious communication limitations of the students, limitation of their mental functions, requirement for nursing to ensure basic needs, etc. During the process of education it is also necessary to make sure that the educational intervention reflects the needs of the family and parents' work with the child in the home 
setting. Empirical experience from practical environments suggests that the teacher-parent cooperation is influenced by a number of factors and is not always satisfactory regarding the educational needs of students with SMD. Therefore, an important topic of special education research is investigating the role of the family in educating these students.

Most publications focusing on the families of persons with SMD address the issue of the educational process in a limited extent. An analysis of professional literature and papers in international databases revealed that a frequent topic was the quality of life of the families with an individual suffering from SMD (Michalík, 2011; Carona et al., 2012; Vohra et al., 2014, etc.), and the economic position and support of the families with children with SMD (Kyzar et al., 2012; Tadema \& Vlaskamp, 2009; Dobson et al., 2001; Whiting, 2014, etc.).

A significant topic in this area is coping with the child's disability (Bigge, Best, Heller, 2010), application of coping mechanisms in dealing with the child's disability (Štěrbová \& Kudláček, 2014; Trute, Benzies, Worthington, 2011; Lin, 2000, etc.), significance of resilience of the families in this process (Greeff \& Nolting, 2013) and similar topics.

In terms of early care, a well-documented topic is working with families with SMD at an early age. Numerous research studies focused on the communication between family members and children with SMD (Wilder \& Granlund, 2003; Grove et al., 1999; Light, 1985, etc.) Available research studies also focus on the involvement of children with SMD in family activities (Axelsson, Granlund, Wilder, 2013; Axelsson, Imms, Wilder, 2014) as well as parents' participation in family and school-based activities (Fishman \& Nickerson, 2014). A significant aspect of the family environment is the issue of siblings with SMD (Roper et al., 2014; Houssier \& Vibert, 2013).

Specific topics of current research studies include mapping the perspectives of children with SMD as seen by their parents (Poon et al., 2013), areas of support where families with persons with SMD require help, and a familyoriented approach (Jansen, Putten, Vlaskamp, 2012; Jansen et al., 2014), sustainability of daily routines and social networks of families with severe multiple disabilities (Wilder \& Granlund, 2015), effect of parenthood on adults with SMD (Evans, Darrah, Galambos, 2010) or parents' psychosocial status (Ulus et al., 2012).

Professional popularization literature addresses the life stories of families with persons with SMD (Chvátalová, 2012; Krejčová, Strnadová, Vágnerová, 2009).

Topics associated with the role of the family in educating students with SMD were included in our project "Research of the quality of life of selected groups of persons with special needs (IGA_PdF_2014008)". 


\section{Research methodology}

To research the role of the family in educating students with SMD we used the data from a quality-based survey aimed at education of students with severe physical, mental and communication impairment in Czech schools. These data were complemented with data from a survey aimed exclusively at specific topics relating to the families of students with SMD in the educational process.

\section{Research of the educational process in students with multiple disabilities}

The methodology of this research was described in a different paper (Kantor et al., 2014); therefore, only basic research data will be summarized. The research study analysed the educational process according to a process scheme as described by Průcha (2009) arranged into input determinants, course and outcomes of the educational process. The objective of the research was to map various educational processes that affect students with SMD according to an analysis of social interaction as one of the fundamental educational phenomena. The research design was of a mixed type, primarily based on quality-oriented procedures and complemented with a questionnaire survey. Data collection was performed by means of semi-structured interviews with 45 teachers, content analysis of 30 individual educational plans, 30 verbal assessments and all-day observation of the teacher-student interaction in four students. The questionnaire survey included a total of 101 teachers. The aim of the questionnaire survey was to test certain topics, for which we had insufficient justification in the data set and which could not be triangulated with data from various sources.

For data analysis we used open, axial and selective coding. This procedure was used to develop models for educational processes in the area of adaptation, interaction and development of interpersonal relationships, stimulation, diagnostics and evaluation, self-attendance, saturation of cognitive and aesthetic abilities, processes aimed at the students' health-related needs, coping with risk behaviour and other difficulties, processes of personality development and processes of student-environment interactions.

This text includes unpublished results of the above mentioned research study, which relate to special education interventions at a family level. As far as open coding is concerned, family-related data were divided into the following groups:

- Family needs with respect to a special education intervention.

- Data relating to the process of the parents' coping with the child's disability and acceptance of the child's real possibilities.

- Course of a special education intervention in working with the child's family. 


\section{Follow-up survey aimed at the role of the families of students with severe multiple disabilities in the educational process}

The data set from the above described research study did not show sufficient saturation in terms of family-oriented topics. Therefore, the follow-up survey focused solely on these topics. The aim of the survey was to complement the data of the above specified topics and use them to develop a model for the description of a special education intervention for working with the child's family. In the survey we used semi-structured interviews with the teachers of students with SMD. The following criteria were used to select the teachers:

- The teachers need to have a degree in special education; Bachelor's degree as a minimum.

- The teachers need to have at least five years of practical experience with educating students with severe multiple disabilities.

The survey included a total of 5 teachers. This sample was recruited by means of intentional selection using personal contacts in relevant institutes. Before the visits to individual classes were made the class teacher was informed and a consent to his/her participation in the survey was obtained. The course of the interview corresponded with usual interview stages, from preparatory and initial stage, through rise and contact reinforcement, core, to conclusion and termination. During the preparatory and initial stage the interviewee was motivated and familiarized with the purpose of the survey, methods of data recording and ethical principles, and guaranteeing anonymity. The interviews took approximately 30-45 minutes, in one case the total time exceeded 60 minutes.

The basic interview structure included establishing contact and conveying information about the purpose of the survey, investigating the needs of families in the context of special education intervention, mapping the way in which the process of coping with disability influences special education intervention and an analysis of tasks and course of special education intervention in working with the child's family.

During the course of the survey we also managed to carry out two short interviews with parents of students with SMD. However, due to their low response relevance these are only included as an additional source of information.

After all interviews we transcribed the data into a written form and prepared the text material for a quality-based analysis. The analysis used open coding including response quantification. We also searched for original and contradictory statements to be used for theory development. The data were classified into categories; these survey outcomes were compared with the data acquired through an analysis of the educational process of students with SMD. We completed and deepened the categories related to the topic of the survey. 
During the next stage, i.e. axial coding, we searched for associations between individual categories and justification of these associations in the data material. The members of the research team discussed which categories and associations were relevant in terms of the issue in question. After that we performed a second order reduction and developed a visual scheme that represents the theoretical model for special education intervention at the level of the families of students with SMD. This model is shown in Fig. 1.

The development of this model reflected the classification of the process scheme of the educational process because monitoring education as a process and classification into input determinants, course and outputs of education enables to monitor the development of education in time and to identify substantial educational outputs. This concept is based on the current requirement for the identification and measurability of the outcomes of educational as well as therapeutic interventions. Regarding the fact that the scheme shown in Fig. 1 is a comprehensive theoretical construct, the following chapter includes a description of its basic categories and associations.

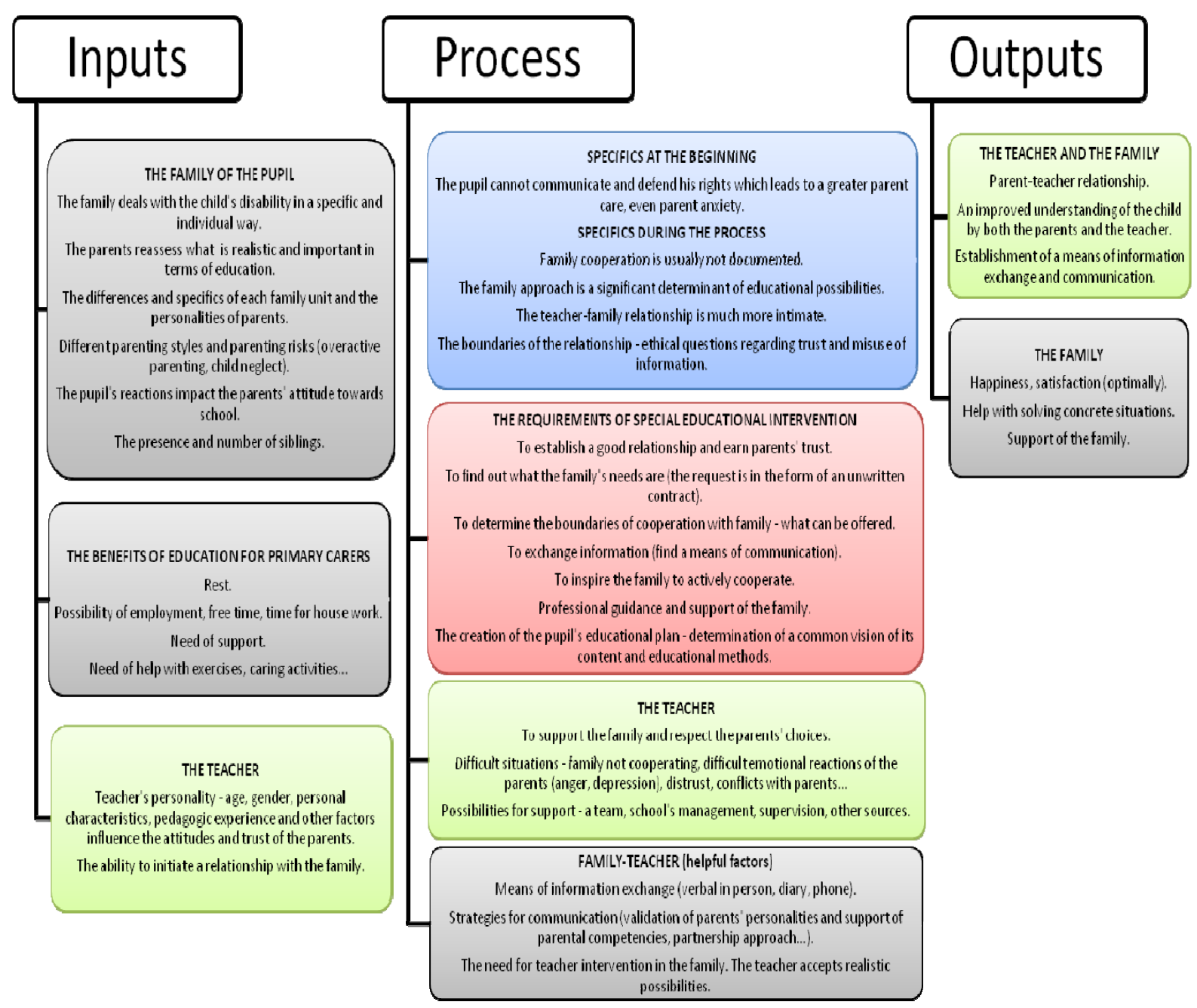

Figure 1. Special education intervention model at the level of the families of students with severe multiple disabilities 


\section{Description of the special education intervention model}

The model shown in Fig. 1 includes categories classified into input determinants, course and outputs of the educational process. There are various associations and processes between the inputs, course and outputs of the educational process.

\section{Needs and expectations of the student's family in the context of education}

The first possible association relates to the expectation of the parents of a student with SMD concerning the educational content and its relevance to the student's family. An analysis of semi-structured interviews with 45 teachers resulted in a body of material shown in Table 1 . This table describes the needs of the parents of students with SMD in relation to education, including response quantification (in the presence column).

Table 1. Family needs with respect to education

\begin{tabular}{|l|l|}
\hline Subcategories & Presence \\
\hline Parents' rest. & 25 \\
\hline Parents want their children to go to school and enjoy themselves at school. & 10 \\
\hline Parents have time to go to work or have time for themselves. & 8 \\
\hline Helping parents with feeding children and other tasks. & 4 \\
\hline Parents do not want their children to be excluded from social activities. & 3 \\
\hline Parents expect that education will improve communication with their child. & 2 \\
\hline
\end{tabular}

During the first years of education the opinions and expectations of parents concerning the content of education provided to their children is formed (at the beginning of school attendance some parents of children with SMD expected that their children would learn the basic trivia skills although these skills significantly exceed the capabilities of these students). As revealed by an analysis of educational documents, the needs and expectations of families are not documented in any way, even though individual educational plans need to be approved by legal representatives. It is questionable which family expectations and needs could be explicitly defined in the students' educational documents. An analysis of the table above (Table 1) revealed the following conclusions:

- Some family needs relate exclusively to the school environment. For example the teachers stated that one of the objectives was to improve the students' communication abilities. At the same time however, the transfer of this ability and its use outside the school environment was not documented at all (generalization of acquired abilities outside the school environment should be a crucial part of training). 
- The school takes over a part of nursing activities concerning basic physical needs of students with SMD. Ensuring the basic physical needs (feeding, lifting on the toilet, caring for incontinent students, etc.) represents a great time and personnel investment within the educational process. The need for saturation of the basic physical skills is specified in the educational document only if the presence of an assistant teacher is required in the class. We believe that the educational outcomes should be documented more thoroughly as well.

- All work with families (professional consultations, counselling and leadership) is not documented in any way even though this represents an inseparable and important part of special education intervention in students with SMD.

- Obviously, some education-related family needs are not and cannot be documented. For example when a child stays at school, his/her parents have time to fulfil their needs (this applies especially to primary carers).

\section{Coping with the child's disability in the context of education}

The data that we acquired during the research about the association between coping with the child's disability and education are as follows:

- Through school performance achieved by the child the parents are confronted with the real level of educational abilities and educational potential. This confrontation might result in temporary crises.

- Becoming aware of the real educational possibilities of the child might deepen depressions in the parents or promote aggressive confrontation with the environment.

- Also, the teachers pointed to the significance of a good teacher-parent relationship, which can support the parents in a difficult life situation.

- The process of the parents coping with their child's disability might be reflected in the communications with the teacher. An example is ventilation of accumulated tension and anger of the parents, frequently as a result if irrelevant stimuli that trigger these situations.

- In many cases the parent-teacher relationship is an intimate and friendly one, as a result of which the parents often share family and personal difficulties. As a consequence, some parents use the teacher as a confidant to share their own problems and difficulties. If the teachers are willing to take this role, they become burdened by a considerable mental load.

- One of the most serious fears on the part of the parents is the future of their child in adulthood. These concerns are caused by a low degree of self-determination and defence of the rights of their children. During the interviews one of the parents said that it was more difficult to 
accept the idea of their child surviving into adulthood rather than dying during their life.

\section{Tasks and course of special education intervention}

An analysis of the semi-structured interviews was used to develop categories relating to special education intervention tasks with respect to the families of students with SMD. These categories are shown in Table 2.

Table 2. 3.3 Tasks of special education intervention

\begin{tabular}{|l|l|}
\hline Category & $\mathbf{P}$ \\
\hline $\begin{array}{l}\text { Development of an effective communication method compensating for the } \\
\text { students' inability to convey significant information to their parents (the teachers } \\
\text { often meet the parents on a daily basis, apart from personal consultations they use } \\
\text { the students' diaries, email and telephone communication in urgent cases). }\end{array}$ & 14 \\
\hline $\begin{array}{l}\text { Family leadership and counselling provided to parents following the students' } \\
\text { education (e.g. in the area of self-attendance, behaviour issues, leisure activities, } \\
\text { sibling relationships, etc.) }\end{array}$ & 12 \\
\hline $\begin{array}{l}\text { Promotion of the parents' participation and activity in the students' social } \\
\text { occasions - community events exceeding the scope of the educational process } \\
\text { (carnivals, extra-curricular performances, class visits to the child's home } \\
\text { environment). }\end{array}$ & 10 \\
\hline $\begin{array}{l}\text { Winning the parents' trust (the parents have a strong need to test the teacher and } \\
\text { make sure that they can rely on the teacher in terms of child care). }\end{array}$ & 8 \\
\hline Explain to the parents the significance of the content of education for their child. & 11 \\
\hline Winning the parents' collaboration in educating their child. & 12 \\
\hline $\begin{array}{l}\text { Development of a partnership and a respecting method of communication between } \\
\text { the teachers and the parents. }\end{array}$ & 5 \\
\hline $\begin{array}{l}\text { Helping parents to understand the preferences, motivations and behaviours of their } \\
\text { children. }\end{array}$ & 2 \\
\hline
\end{tabular}

\section{Discussion}

The conclusions presented are based on the description and analysis of the text material accumulated during the quality-oriented survey. It would be useful to complement these research conclusions with a more extensive research survey carried out in the families. From a methodological point of view, such research is much more difficult as the researcher disrupts the intimacy of the family environment, faces the parents' difficulties in reflecting on some topics (particularly those of a personal nature), concerns and a low degree of willingness to participate in research surveys. This especially applies to topics such as coping with the child's disability. However, some topics of this research survey could be investigated in a quantity-based way, e.g. expectations of the parents and significance of education for the parents. 
In assessing data validity we need to take into account the fact that the data was acquired primarily from the teachers. Regarding the long-term experience and many years of relationships with the families, the teachers' reflections can be of high response relevance. On the other hand, lacking a comparison with data acquired directly from the families, these conclusions can be regarded a mere hypothetical construct that needs to be verified by further research.

We also need to be critical about the validity regarding the used data sources. In quality-based research one of the procedures ensuring data validity is triangulation and comparison of conclusion acquired from various data sources. This research study was primarily based on semi-structured interviews because other sources were unavailable (in the educational documents we found almost no data on family issues and education, this was also an issue in the case of other data collection methods). In such circumstances the only possibility is to work with available material, being aware that a sufficient degree of validity cannot be ensured.

\section{Summary of recommendations}

The summary of recommendations based on this paper is as follows:

- The educational documents need to include the objectives and outcomes relating to the student's family environment (and/or extracurricular environment). For example, this includes professional guidance of the parents, transfer of skills acquired in an extracurricular environment, etc.

- Nursing activities should be used in the educational process. In some students these activities take more time than education.

- The teacher-parent communication represents a significant compensatory mechanism that offsets the students' communication deficiencies and helps both the teachers and families to better understand the students with SMD. Specific compensatory mechanisms described in this text are significant in order to deepen the knowledge about special education methods. This includes sharing of situations and experiences of the student from a school or home environment, studying of the personal history of the student by the teacher, visits to the student's home and learning about the immediate context of the student's life, etc.

- $\quad$ Process of coping with the student's disability by the parents strongly influences the confrontation with the student's real educational possibilities. The course of education is characterized by a shift from excessive (sometimes unrealistic expectations) at the beginning of school attendance to reasonable understanding of the student's educational possibilities. In relation to the process of coping with the 
student's disability the teachers described a considerable parents' investment into their child's education at the beginning of school attendance, which in many cases results in exhaustion of the parents' mental resources (in some cases this exhaustion results in neglecting the child and a loss of belief in the significance of continuous work with the child). It might be beneficial for the teacher if he/she is able to realistically assess the parents' possibilities to invest in the care for their child and their child's school education.

\section{Conclusion}

The paper deals with the association between the family environment of students with multiple disabilities and the educational process. In spite of the discussed methodological limitations the paper presents a summary of conclusions with a sufficient data background. These conclusions relate to the description of family needs with respect to the educational process, tasks and course of a special education intervention and the way in which the process of coping with the child's disability influences student education.

\section{References}

Axelsson, A. K., Granlund, M., Wilder, J. (2013). Engagement in family activities. Child: Care, Health and Development. 2013;39/4:523-534.

Axelsson, A. K., Imms, Ch., Wilder, J. (2014). Strategies that facilitate participation in family activities of children and adolescents with profound intellectual and multiple disabilities. 2014;36/25:2169-2179.

Bigge, J., Best, J., S., Heller, K., W. (2010). Teaching Individuals with Physical or Multiple Disabilities. New York: MacmillanPublishing Copany.

Carona, C. et al. (2013). The Disability Paradox Revisited. Journal of Child nad Family Studies. 2013;22:971-986.

Chvátalová, H. (2012). Jak se žije dětem s postižením po deseti letech. Praha: Portál.

Dobson, B. et al (2001). The Impact of Childhood Disability on Family Life. New York: Joseph Rowntree Foundation.

Evans, J. M., Darrah, J., Galambos, N. (2011). The Parenting Journey of Mothers of Young Adults with Multiple Impairments. Journal of Developmental and Physical Disabilities.2011;23:183-193.

Fishman, C. E., Nickerson, A. B. (2014). Motivations for Involvement: A Preliminary Investigation of Parents of Students with Disabilities. Journal of Child and Family Studies. 2014;24:523-535.

Greeff, A. P., Nolting, C. (2013). Resilience in Families of Children With Developmental Disabilities. Families, Systems and Health. 2013;31/4:396-405.

Grove, N. et al. (1999). See what I mean: Interpreting the meaning of communication by people with severe and profound intellectual disabilities. Journal of Applied Research in Intellectual Disability. 1999;12:190 - 203.

Houssier, S., Vibert, F. (2013). Siblings relationship in family of adolescents with multiple disabilities. Neuropsychiatrie de l'Enfanceet de l'Adolescence. 2013;61/3:183-189. 
Jansen, S. L. G. (2014). Family-centredness of professionals who support people with profound intellectual and multipledisabilities. Research in Developmental Disabilities. 2014;35/7:1623-1630.

Jansen, S. L. G., Putten, A. A. J., Vlaskamp, C. (2012). What parents find important in the support of a child with profound intellectual and multiple disabilities. Child: Care, Health and Development. 2012;39/3:432-441.

Kantor, J. et al. (2014). Kreativní př́stupy v rehabilitaci osob s těžkým kombinovaným postižením. Olomouc: Vydavatelství Univerzity Palackého.1 432

Krejčová, L., Strnadová, I., Vágnerová, M. (2009). Náročné mateřství. Praha: Karolinum.

Kyzar, B. K. et al. (2012). The Relationship of Family Support to Family Outcomes: A Synthesis of Key Findings From Research on Severe Disability. Research \& Practice for Persons with Severe Disabilities.2012;37/1:31-44.

Light, J. (1985). The communicative interaction patterns of young nonspeaking physically disabled children and their primary caregivers. Toronto: University of Toronto.

Lin, S. (2000). Coping and adaptation on families of children with cerebral palsy. Exceptional Children. 2000;66:201 - 218.

Michalík, J. et al. (2011). Kvalita života osob pečujících o člena rodiny s těžkým zdravotním postižením. Olomouc: Vydavatelství UP.

Poon, K. (2013). Parental perspectives on the importance and likelihood of adult outcomes for children with Autism Spectrum Disorders, Intellectual Disabilities or MultipleDisabilities. Research in Autism Spectrum Disorders. 2013;7/2:382-390.

Průcha, J. (2009). Moderní pedagogika. Praha: Portál.

Roper, S. O. et al. (2014). Caregiver Burden and Sibling Relationships in Families Raising Children With Disabilities and Typically Developing Children. Families, Systems and Health. 2014;32/2:241-246.

Štěrbová, D., Kdláček, M. (2014). Deaf-blindness: Voices of mothers concerning leisure-time physical activity and coping with disability. Acta Gymnica.2014;44/4:193-201.

Tadema, C. T., Vlaskamp, C. (2009). The time and effort in taking care for children with profound intellectual and multiple disabilities: British Journal of Learning Disabilities.2009;38:41-48.

Trute, B., Benzies, K. M., Worthington, C. (2011). Mother Positivity and Family Adjustment in Households with Children with a Serious Disability. Journal of Child and Family Studies. 2011; 21:411-417.

Ulus, Y. et al. (2012). Functional disability of children with spina bifida: Its impact on parents psychological status and family functioning. Developmental Neurorehabilitation. 2012;15/5:322-328.

Vohra, R. et al. (2014). Access to services, quality of care, and family impact for children with autism, other developmental disabilities, and other mental health conditions. Autism: The International Journal of Research \& Practice. 2014;18/7:815-826.

Whiting, M. (2014). Children with disability and complex health needs: the impact on family life. Nursing Chlidren and Young People. 2013;26/3:26-30.

Wilder, J., Granlund, M. (2003). Behavior style and interaction between seven children with multiple disabilities and their caregivers. Child: Care, Health and Development.2003;29:559 - 567.

Wilder, J., Granlund, M. (2015). Stability and Change in Sustainability of Daily Routines and Social Networks in Families of Children with Profound Intellectual and Multiple Disabilities. Journal of Applied Research in Intellectual Disabilities. 2015;28/2:133144. 